\title{
COMPARATIVE STUDY OF PRETREATMENT WITH ROCURONIUM AND VECURONIUM IN POST SUCCINYLCHOLINE FASCICULATION, INTUBATION CONDITION AND MYALGIA
}

\author{
Joshi Vyankatesh $S^{1}$, Todkari Kiran $V^{2}$, Deshpande Satish $G^{3}$
}

${ }^{1}$ Assistant Professor, Department of Anaesthesiology, Government Medical College, Latur, Maharashtra. ${ }^{2}$ Assistant Professor, Department of Anaesthesiology, Government Medical College, Latur, Maharashtra. 3 Professor and HOD, Department of Anaesthesiology, Government Medical College, Latur, Maharashtra.

\begin{abstract}
Succinylcholine has quicker onset of action, reliable and excellent intubating conditions with shorter duration but has undesirable side effects as fasciculation, rise intraocular pressure, rise in intragastric pressure and subsequent vomiting and regurgitation hyperkalaemia, rise serum CPK levels, myalgia and myoglobinuria. It is contraindicated in anticipated difficult intubation, severe kidney and liver disease, trauma, pregnancy, etc. Many methods were tried to decrease these side effects of succinylcholine by many scientists. Pretreatment with non-depolarizing muscle relaxant is one of that which found to be successful. In the present study, Rocuronium and Vecuronium were tried to evaluate their efficacy in reducing post succinylcholine fasciculation, intubating conditions, serum potassium and CPK, myalgia and myoglobin; 150 patients were divided into three groups according to administration normal saline Rocuronium, Vecuronium as pretreatment before Succinylcholine where general anaesthesia administration was essential. It was observed that pretreatment with Rocuronium and Vecuronium significantly reduced incidence and severity of fasciculation, better intubating conditions, no change in serum potassium and CPK levels, reduction in Myalgia and no change in myoglobin postoperatively. Rocuronium was found to be better than Vecuronium in all respects to minimize side effects of Succinylcholine.
\end{abstract}

\section{KEYWORDS}

Succinylcholine, Excellent Endotracheal Intubation, Fasciculations, Myalgia, Hyperkalaemia, Pretreatment with NDR, Reduction in Side Effects, Rocuronium, Vecuronium.

HOW TO CITE THIS ARTICLE: Vyankatesh JS, Kiran TV, Satish DG. Comparative study of pretreatment with rocuronium and vecuronium in post succinylcholine fasciculation, intubation condition and myalgia. J. Evolution Med. Dent. Sci. 2016;5(38): 2319-2324, DOI: $10.14260 /$ jemds/2016/539

\section{INTRODUCTION}

Triad of general anaesthesia constitutes hypnosis, analgesia and muscle relaxation and specific drugs are being used to produce each of these parameters of balanced anaesthesia. It is generally accepted that the ideal muscle relaxant for endotracheal intubation should have specificity, rapid onset of action, readily controllable intensity, profound muscle relaxation, free from haemodynamic changes and rapid with complete recovery.

Succinylcholine was introduced in clinical practice by S. Thesleff and Folds et al (1952) after its introduction by Daniel Bovet (1935). Since its introduction up till now, it is the most ideal drug for endotracheal intubation after induction of anaesthesia. It has got rapid onset of action and produces ideal intubating conditions. In spite of these advantages, it is associated with some untoward actions its limitations of use in burns, neuromuscular disorders, trauma, nerve injury, liver and kidney dysfunction.

These depolarizing muscle relaxants are associated with occurrence of fasciculations, post-operative myalgia, rise in intraocular pressure, hyperkalaemia, rise in serum creatinine phosphokinase and myoglobinuria.

To reduce or avoid these undesirable effects associated with succinylcholine many methods have been tried and are being tried as reducing the dose, use of Vitamin C,

Financial or Other, Competing Interest: None.

Submission 30-03-2016, Peer Review 23-04-2016,

Acceptance 29-04-2016, Published 12-05-2016.

Corresponding Author:

Dr. Joshi Vyankatesh $S$

Shriram Nivas,

Near New SSC Board Office,

Tagor Nagar,

Latur-413512.

E-mail: vyankatesh93@rediffmail.com

DOI: $10.14260 /$ jemds/2016/539 self-taming, pretreatment with non-depolarizing muscle relaxants, Diazepam, Lignocaine, Nifedipine, Alfentanil, etc. with merits and demerits of each technique or pharmacological agent.

In the present study, we have tried the efficacy of pretreatment with Rocuronium and Vecuronium before administration of Succinylcholine for fasciculations, intubating conditions, myalgia, serum potassium, serum $\mathrm{CPK}$ and urine myoglobin.

\section{MATERIAL AND METHOD OF STUDY}

In the present study, 150 patients of ASA Grade I and II between age range of 20-65 years of either sex undergoing elective surgery requiring general anaesthesia with endotracheal intubation were included. The patients with neuromuscular disorders, metabolic diseases, renal or hepatic dysfunction, pregnancy and anticipated difficult intubation, extremes of age, cachexic and emaciated patients were excluded from study. All patients were evaluated for fitness for anaesthesia and written informed consent was obtained from each. Routine blood and urine investigations were carried.

These 150 patients were divided into 3 equal groups of 50 each.

- $\quad$ Group NS - Receiving no pretreatment, received $2 \mathrm{~mL}$ of normal saline and served as control group.

- Group V - Received Inj. Vecuronium $0.01 \mathrm{mg} / \mathrm{kg}$ diluted up to $2 \mathrm{~mL}$.

- $\quad$ Group R - Received Inj. Rocuronium 0.06 mg/kg diluted up to $2 \mathrm{~mL}$

A standard anaesthesia technique was followed in all patients. On the operation table vital signs as pulse rate, blood pressure was noted and all patients were attached monitoring devices. Before administration of anaesthesia drugs, blood 
samples were taken for estimation of preoperative serum potassium and creatinine phosphokinase levels. All patients received premedication with Inj. Glycopyrrolate $4 \mu \mathrm{gm} / \mathrm{kg}$, Inj. Diazepam $50 \mathrm{mcg} / \mathrm{kg}$ and Inj. Pentazocine $0.3 \mathrm{mg} / \mathrm{kg}$.

Then according to group distribution, each patients received either $2 \mathrm{~mL}$ of normal saline in Group NS, Inj. Vecuronium $0.01 \mathrm{mg} / \mathrm{kg}$ diluted up to $2 \mathrm{~mL}$ in Group V and Inj. Rocuronium $0.06 \mathrm{mg} / \mathrm{kg}$ diluted up to $2 \mathrm{~mL}$ in Group R prior to induction of anaesthesia. All patients were induced with Inj. Thiopentone sodium $5 \mathrm{mg} / \mathrm{kg}$ followed by Inj. Succinylcholine $1.5 \mathrm{mg} / \mathrm{g}$ IV. All patients were observed for presence of fasciculations, intubating conditions, serum potassium and serum CPK (samples taken 2 minutes after administration of Succinylcholine), urine sample was taken with catheterization 20 minutes after Inj. Succinylcholine for myoglobin estimation.

\section{Fasciculations were Observed as}

No Fasciculations - Nil

Very fine only at finger tips and/or facial muscles - Mild

Minimal fasciculations on trunk and extremities - Moderate Vigorous fasciculations on trunk and extremities - Severe

Intubating conditions were graded as jaw relaxation, vocal cord position and patient's response to intubation 0 to 3 points were given according to each criteria and intubation score was obtained.

\begin{tabular}{|c|c|c|c|}
\hline \multicolumn{4}{|c|}{ Intubating Condition } \\
\hline Score & $\begin{array}{c}\text { Jaw } \\
\text { Relaxation }\end{array}$ & $\begin{array}{c}\text { Vocal Cord } \\
\text { Position }\end{array}$ & $\begin{array}{c}\text { Response to } \\
\text { Intubation }\end{array}$ \\
\hline 0 & Poor & Closed & Severe Coughing \\
\hline 1 & Minimal & Closing & Mild Coughing \\
\hline 2 & Moderate & Moving & $\begin{array}{c}\text { Slight } \\
\text { Diaphragmatic } \\
\text { Movements }\end{array}$ \\
\hline 3 & Good & Open & None \\
\hline
\end{tabular}

8 - 9 score with excellent intubating conditions.

\begin{tabular}{|c|c|}
\hline Intubating Condition & Total Score \\
\hline Excellent & $8-9$ \\
\hline Good & $6-7$ \\
\hline Fair & $3-5$ \\
\hline Poor & $0-2$ \\
\hline
\end{tabular}

Intraoperatively anaesthesia was maintained on nitrous oxide, oxygen, halothane and intermittent doses of long-acting muscle relaxant on Bain's circuit. After completion of operative procedure, reversal was carried out with Inj. Glycopyrlolate $10 \mathrm{mcg} / \mathrm{kg}$, Inj. Neostigmine $0.008 \mathrm{mg} / \mathrm{kg}$. All patients were extubated after complete recovery and shifted to recovery room.

\section{Myalgia}

There were no restrictions for postoperative ambulation of the patients. Myalgia was assessed on day 1 and day 3 and enquired about the presence of muscle pain postoperatively, site of pain and whether mild, moderate or severe.

\section{Nil}

No muscle pain.

\section{Mild}

Muscle pain or stiffness with no limitation of activity.

\section{Moderate}

Muscle pain and/or stiffness all over body, but no limitation of activity.

\section{Severe}

Muscle pain and stiffness, limitation of activity requiring treatment.

All observations were statistically evaluated with Z test or Chi square test for statistical significance.

\section{OBSERVATIONS}

150 patients were divided into 3 equal groups according to pretreatment received as shown in Table No. I.

\section{Age Distribution was as shown in Table No. II}

There were maximum numbers of patients in age range of 3140 years followed by $41-50$ years in all three groups. The mean age range was $37.36 \pm 8.76$ in Group NS, 39.96 \pm 8.83 in Group V and $35.53 \pm 9.69$ in Group R. There was no significant difference in three groups as age range was concerned.

\section{Sex Distribution was as shown in Table No. III}

There was no significant difference as far as sex distribution was concerned in all three groups.

\section{Distribution According to ASA Grading was as shown in Table No. IV}

There was no significant difference in ASA grading in three groups.

\section{Weight Wise Distribution was as shown in Table No. V}

There was equal distribution of patients in three groups when weight was considered. Mean weight was $58.68 \pm 9.51 \mathrm{~kg}$ in Group NS, 58.58 $\pm 8.95 \mathrm{~kg}$ in Group V and 58.88 $\pm 9.22 \mathrm{~kg}$ in Group R. There was no significant difference.

All these Patients Were Observed for Incidence of Fasciculations after Administration of Succinylcholine as shown in Table No. VI

It was observed that all patients in group NS had fasciculations. $28 \%$ had mild, $60 \%$ had moderate and $12 \%$ had severe fasciculations in Group NS. In Group V, there were no fasciculations in $52 \%$, mild in $36 \%$ and moderate in $12 \%$. In Group R, $76 \%$ had no fasciculations and $24 \%$ had mild fasciculations. Thus incidence of fasciculations was minimum in Rocuronium group followed by Vecuronium group as compared to control NS Group. The findings were highly significant in Rocuronium and Vecuronium as compared to control Group NS.

The Intubating Conditions Were Assessed and Noted as shown in Table No. VII

In most of the patients, excellent intubating conditions were observed. Pretreatment with either Vecuronium or Rocuronium does not interfere with intubating conditions after Succinylcholine. There was no significant difference in three groups as far intubating conditions were concerned.

The Intubating Conditions were also Assessed as Intubation Score as shown in Table No. VIII

Intubation score of 9 was noted in $60 \%, 48 \%$ and $56 \%$ of patients of Group NS, Group V and Group R respectively. Score 
7 - 8 was noted in $36 \%, 41 \%$ and $38 \%$ in these three groups. Thus intubation score was almost identical in control and Group V and R. The score was insignificantly better in Rocuronium group as compared to Vecuronium group. Mean intubation score, there was no significant difference in three groups.

Serum Potassium Levels Were Estimated before Administration of Anaesthesia and 2 minutes after Administration of Succinylcholine as shown in Table No. IX

In all three groups, serum potassium levels were in normal range of $3.5-5.3 \mathrm{mEq} /$ lit preoperatively in all patients. There was no significant difference in mean serum $\mathrm{K}$ levels preoperatively. After 2 minutes of Succinylcholine administration, there was insignificant rise in serum $\mathrm{K}$ in Group NS as compared to Group V and Group R. There was no significant difference in serum $\mathrm{K}$ in Group V and Group R after 2 minutes.

Mean rise in serum $\mathrm{K}^{+}$was $0.46 \mathrm{mEq} / \mathrm{lit}$ in Group NS, 0.21 $\mathrm{mEq} / \mathrm{lit}$ in Group V and $0.10 \mathrm{mEq} / \mathrm{lit}$ in Group R. It was statistically insignificant.

Serum Creatinine Phosphokinase CPK Preoperatively and 24 hours after Administration of Succinylcholine was noted as shown in Table No. $X$

Preoperatively, serum CPK levels similar in three groups in all patients. In most of the patients CPK levels were in range of 50-150 units/lit in all patients. Serum CPK levels were significantly increased in Group NS as compared to Group V and Group R. The levels were insignificantly low in Group R as compared to Group V. Mean rise in CPK levels was 205 units/lit in Group NS, 79.28 units/lit in Group V and 35 units/lit in Group R.

Urine myoglobin was estimated by qualitative test 20 minutes after administration of Succinylcholine as shown in Table No. XI

Urine myoglobin was present in $32 \%$ of patients in Group NS and $8 \%$ of patients in Group V only. Urine myoglobin was absent in all patients of Group R.

All Patients were asked for Postoperative Muscle pain or Stiffness on day 1 and day 3 as noted in Table No. XII

On day 1, postoperative myalgia (Muscle pain or stiffness) was noted to be mild or moderate in more number of patients in Group NS as compared to Group V and Group R. There were $8 \%$ of patients with severe postoperative myalgia only in group NS. On day there were more number of patients with nilto-mild muscle pain in Group $\mathrm{R}$ as compared to Group V. On day 3, mild-to-moderate and severe myoglobin was noted in Group NS patients only. Almost $90-98 \%$ of patients had nil-tomild Myalgia in Group V and Group R. As far as post-operative myalgia was concerned Group R was better on day 1 and day 3 as compared to Group V and Group NS.

\begin{tabular}{|c|c|c|c|c|c|c|}
\hline \multirow{2}{*}{ Fasciculations } & \multicolumn{2}{|c|}{ Group NS } & \multicolumn{2}{c|}{ Group V } & \multicolumn{2}{c|}{ Group R } \\
\cline { 2 - 7 } & No. of Patients & \% & No. of Patients & \% & No. of Patients & \% \\
\hline Nil & 0 & $0 \%$ & 26 & $52 \%$ & 38 & $76 \%$ \\
\hline Mild & 14 & $28 \%$ & 18 & $36 \%$ & 12 & $24 \%$ \\
\hline Moderate & 30 & $60 \%$ & 6 & $12 \%$ & 0 & $0 \%$ \\
\hline Severe & 6 & $12 \%$ & 6 & & 50 & $0 \%$ \\
\hline \multicolumn{2}{|c|}{ Table 6: Showing Incidence of Fasciculations } \\
\hline
\end{tabular}

All Patients Were Observed for Intraoperative and Postoperative Complications as shown in Table No. XIII Overall, the incidence of dreadful intraoperative or postoperative complications was very less in all three groups, that too the incidence was negligible in Group $\mathrm{R}$ as compared to Group V and Group NS.

\begin{tabular}{|c|c|c|c|}
\hline Groups & $\begin{array}{c}\text { Drug for Pre- } \\
\text { treatment }\end{array}$ & Dose & $\begin{array}{c}\text { No. of } \\
\text { Patients }\end{array}$ \\
\hline $\begin{array}{c}\text { Group } \\
\text { NS }\end{array}$ & Normal saline & $2 \mathrm{~mL}$ & 50 \\
\hline Group V & Vecuronium & $\begin{array}{c}0.1 \mathrm{mg} / \mathrm{kg} \\
\text { in } 2 \mathrm{~mL}\end{array}$ & 50 \\
\hline Group R & Rocuronium & $\begin{array}{c}0.06 \mathrm{mg} / \mathrm{kg} \\
\text { in } 2 \mathrm{~mL}\end{array}$ & 50 \\
\hline \multicolumn{3}{|c|}{ Table 1: Showing Group Distribution } \\
\hline
\end{tabular}

\begin{tabular}{|c|c|c|c|}
\hline $\begin{array}{c}\text { Age in } \\
\text { Years }\end{array}$ & $\begin{array}{c}\text { Group NS } \\
\text { No. of } \\
\text { Patients }\end{array}$ & $\begin{array}{c}\text { Group V } \\
\text { No. of } \\
\text { Patients }\end{array}$ & $\begin{array}{c}\text { Group R } \\
\text { No. of } \\
\text { Patients }\end{array}$ \\
\hline $21-30$ & 10 & 11 & 12 \\
\hline $31-40$ & 24 & 24 & 24 \\
\hline $41-50$ & 12 & 10 & 10 \\
\hline $51-60$ & 4 & 5 & 4 \\
\hline $\begin{array}{c}\text { Mean } \\
\text { Age }\end{array}$ & $\begin{array}{c}\mathbf{3 7 . 3 6} \pm \mathbf{8 . 7 8} \\
\text { yrs. }\end{array}$ & $\begin{array}{c}\mathbf{3 6 . 9 6 \pm 8 . 8 3} \\
\text { yrs. }\end{array}$ & $\begin{array}{c}\mathbf{3 5 . 5 3} \pm \mathbf{9 . 6 9} \\
\text { yrs. }\end{array}$ \\
\hline \multicolumn{4}{|c|}{ Table 2: Showing Age Distribution } \\
\hline
\end{tabular}

\begin{tabular}{|c|c|c|c|}
\hline Gender & $\begin{array}{c}\text { Group NS } \\
\text { No. of } \\
\text { Patients }\end{array}$ & $\begin{array}{c}\text { Group V } \\
\text { No. of } \\
\text { Patients }\end{array}$ & $\begin{array}{c}\text { Group R } \\
\text { No. of } \\
\text { Patients }\end{array}$ \\
\hline Male & 31 & 28 & 30 \\
\hline Female & 19 & 22 & 20 \\
\hline \multicolumn{3}{|c|}{ Table 3: Showing Sex Distribution } \\
\hline
\end{tabular}

\begin{tabular}{|c|c|c|c|}
\hline $\begin{array}{c}\text { ASA } \\
\text { Grade }\end{array}$ & $\begin{array}{c}\text { Group NS } \\
\text { No. of } \\
\text { Patients }\end{array}$ & $\begin{array}{c}\text { Group V } \\
\text { No. of } \\
\text { Patients }\end{array}$ & $\begin{array}{c}\text { Group R } \\
\text { No. of } \\
\text { Patients }\end{array}$ \\
\hline I & 35 & 32 & 34 \\
\hline II & 15 & 18 & 16 \\
\hline \multicolumn{3}{|c|}{ Table 4: Showing ASA Grading } \\
\hline
\end{tabular}

\begin{tabular}{|c|c|c|c|}
\hline $\begin{array}{c}\text { Weight } \\
\text { Range in } \\
\text { Kg }\end{array}$ & $\begin{array}{c}\text { Group NS } \\
\text { No. of } \\
\text { Patients }\end{array}$ & $\begin{array}{c}\text { Group V } \\
\text { No. of } \\
\text { Patients }\end{array}$ & $\begin{array}{c}\text { Group R } \\
\text { No. of } \\
\text { Patient }\end{array}$ \\
\hline $41-50$ & 11 & 10 & 9 \\
\hline $51-60$ & 19 & 20 & 21 \\
\hline $61-70$ & 15 & 15 & 15 \\
\hline $71-80$ & 5 & 5 & 5 \\
\hline & 50 & 50 & 50 \\
\hline $\begin{array}{c}\text { Mean } \\
\text { Weight in } \\
\text { kg }\end{array}$ & $\mathbf{5 8 . 6 8 \pm 9 . 5 7}$ & $\mathbf{5 8 . 5 8 \pm 8 . 9 5}$ & $\mathbf{5 8 . 8 8 \pm 9 . 2 2}$ \\
\hline \multicolumn{4}{|c|}{ Table 5: Showing Weight Wise Distribution } \\
\hline
\end{tabular}

J. Evolution Med. Dent. Sci./ eISSN- 2278-4802, pISSN- 2278-4748/ Vol. 5/ Issue 38/ May 12, 2016 


\begin{tabular}{|c|c|c|c|c|c|c|}
\hline \multirow{2}{*}{ Intubating Condition } & \multicolumn{2}{|c|}{ Group NS } & \multicolumn{2}{c|}{ Group V } & \multicolumn{2}{c|}{ Group R } \\
\cline { 2 - 7 } & No. of Patients & $\mathbf{\%}$ & No. of Patients & $\mathbf{\%}$ & No. of Patients & \% \\
\hline Excellent & 42 & $84 \%$ & 39 & $78 \%$ & 41 & $82 \%$ \\
\hline Good & 8 & $16 \%$ & 10 & $20 \%$ & 9 & -- \\
\hline Fair & -- & -- & 1 & $2 \%$ & -- & -- \\
\hline Poor & -- & -- & -- & -- & 50 & \\
\hline \multicolumn{7}{|c|}{ Table 7: Showing Intubating Conditions } \\
\hline
\end{tabular}

\begin{tabular}{|c|c|c|c|c|c|c|}
\hline \multirow{2}{*}{$\begin{array}{c}\text { Intubation } \\
\text { Score }\end{array}$} & \multicolumn{2}{|c|}{ Group NS } & \multicolumn{2}{|c|}{ Group V } & \multicolumn{2}{|c|}{ Group R } \\
\hline & No. of Patients & $\%$ & No. of Patients & $\%$ & No. of Patients & $\%$ \\
\hline 10 & -- & -- & -- & -- & -- & -- \\
\hline 9 & 30 & $60 \%$ & 24 & $48 \%$ & 28 & $56 \%$ \\
\hline 8 & 12 & $24 \%$ & 15 & $30 \%$ & 13 & $26 \%$ \\
\hline 7 & 6 & $12 \%$ & 5 & $10 \%$ & 6 & $12 \%$ \\
\hline 6 & 2 & $4 \%$ & 5 & $10 \%$ & 3 & $\%$ \\
\hline 5 & -- & -- & 1 & $2 \%$ & -- & -- \\
\hline Less than 4 & -- & -- & -- & -- & -- & -- \\
\hline Total & & 50 & & 50 & & 50 \\
\hline Mean & $8.4 \pm 0.85$ & -- & $8.12 \pm 1.08$ & & $8.32 \pm 0.91$ & \\
\hline \multicolumn{7}{|c|}{ Table 8: Showing Intubation Condition Score } \\
\hline
\end{tabular}

\begin{tabular}{|c|c|c|c|c|c|c|}
\hline \multirow{3}{*}{$\begin{array}{c}\text { Serum K } \\
\mathrm{mEq} / \mathrm{lit}\end{array}$} & \multicolumn{6}{|c|}{ No. of Patients } \\
\hline & \multicolumn{2}{|c|}{ Group NS } & \multicolumn{2}{|c|}{ Group V } & \multicolumn{2}{|c|}{ Group R } \\
\hline & Preop & $2 \mathrm{~min}$ & Preop & $2 \mathrm{~min}$ & Preop & $2 \mathrm{~min}$ \\
\hline $3-3.5$ & 4 & 1 & 3 & -- & 4 & 4 \\
\hline $3.6-4.0$ & 11 & 4 & 12 & 11 & 9 & 16 \\
\hline $4.1-4.5$ & 21 & 12 & 19 & 12 & 22 & 17 \\
\hline $4.6-5.0$ & 9 & 18 & 10 & 17 & 9 & 12 \\
\hline $5.1-5.5$ & 5 & 9 & 6 & 8 & 6 & 7 \\
\hline $5.6-6.0$ & -- & 6 & -- & 2 & -- & 2 \\
\hline Mean & $4.34 \pm 0.54$ & $4.81 \pm 0.57$ & $4.36 \pm 0.52$ & $4.55 \pm 0.53$ & $4.34 \pm 0.56$ & $4.44 \pm 0.39$ \\
\hline & & Table & ing Serum $F$ & um Level & & \\
\hline
\end{tabular}

\begin{tabular}{|c|c|c|c|}
\hline \multirow{3}{*}{$\begin{array}{c}\text { Serum CPK Levels in } \\
\text { Units/lit }\end{array}$} & \multicolumn{3}{|c|}{ No. of Patients } \\
\hline & \multicolumn{3}{|c|}{ Preoperative } \\
\hline & Group NS & Group V & Group R \\
\hline Up to 100 & 15 & 15 & 15 \\
\hline $101-200$ & 30 & 29 & 29 \\
\hline $201-300$ & 5 & 6 & 6 \\
\hline \multicolumn{4}{|c|}{ After 24 hours } \\
\hline $0-100$ & 1 & 6 & 9 \\
\hline $101-200$ & 5 & 24 & 32 \\
\hline $201-300$ & 16 & 13 & 9 \\
\hline $301-400$ & 13 & 5 & -- \\
\hline $401-500$ & 12 & 2 & -- \\
\hline$>500$ & 3 & -- & -- \\
\hline Mean Preop & $118.68 \pm 45.4$ & $120.64 \pm 45.39$ & $120.62 \pm 45.57$ \\
\hline Mean 24 hrs. & $323.68 \pm 116.51$ & $199.92 \pm 94.85$ & $155.82 \pm 54.0$ \\
\hline Mean rise & 205 units/lit & 39.28 units/lit & 35 units/lit \\
\hline \multicolumn{4}{|c|}{ Table 10: Showing Serum CPK Levels } \\
\hline
\end{tabular}

\begin{tabular}{|c|c|c|c|c|c|c|}
\hline \multirow{2}{*}{ Urine Myoglobin } & \multicolumn{2}{|c|}{ Group NS } & \multicolumn{2}{c|}{ Group V } & \multicolumn{2}{c|}{ Group R } \\
\cline { 2 - 7 } & No. of Patients & $\%$ & No. of Patients & $\%$ & No. of Patients & \% \\
\hline Present & 16 & $32 \%$ & 4 & $8 \%$ & -- & -- \\
\hline Absent & 34 & $68 \%$ & 46 & $92 \%$ & 50 & $100 \%$ \\
\hline Total & $\mathbf{5 0}$ & & $\mathbf{5 0}$ & & $\mathbf{5 0}$ & \\
\hline
\end{tabular}




\begin{tabular}{|c|c|c|c|c|c|c|}
\hline \multirow{3}{*}{ Myalgia } & \multicolumn{6}{|c|}{ No. of Patients } \\
\hline & \multicolumn{3}{|c|}{ Day 1} & \multicolumn{3}{|c|}{ Day 3} \\
\hline & Group NS & Group V & Group R & Group NS & Group V & Group R \\
\hline Nil & 8 & 36 & 44 & 6 & 30 & 40 \\
\hline Mild & 26 & 10 & 6 & 24 & 15 & 10 \\
\hline Moderate & 12 & 4 & -- & 14 & 5 & -- \\
\hline Severe & 4 & -- & -- & 6 & -- & -- \\
\hline Total & 50 & 50 & 50 & 50 & 50 & 50 \\
\hline \multicolumn{7}{|c|}{ Table 12: Showing Postoperative Myalgia } \\
\hline
\end{tabular}

\begin{tabular}{|c|c|c|c|c|c|c|}
\hline \multirow{2}{*}{ Complications } & \multicolumn{2}{|c|}{ Group NS } & \multicolumn{2}{c|}{ Group V } & \multicolumn{2}{c|}{ Group R } \\
\cline { 2 - 7 } & No. of Patients & $\mathbf{\%}$ & No. of Patients & $\mathbf{\%}$ & No. of Patients & \% \\
\hline Hypotension & 1 & 25 & 2 & 45 & 1 & $2 \%$ \\
\hline Hypertension & 2 & $4 \%$ & 2 & $4 \%$ & 1 & $2 \%$ \\
\hline Bradycardia & 1 & $2 \%$ & -- & -- & -- & 2 \\
\hline Tachycardia & 2 & $4 \%$ & 3 & $6 \%$ & -- & -- \\
\hline Bronchospasm & 1 & $2 \%$ & -- & -- & -- & $\mathbf{8}$ \\
\hline other & -- & -- & $\mathbf{7}$ & $\mathbf{1 4 \%}$ & $\mathbf{4}$ \\
\hline Total & $\mathbf{7}$ & $\mathbf{1 4 \%}$ & $\mathbf{7}$ & \\
\hline
\end{tabular}

\section{DISCUSSION}

Since its introduction by (1955), Succinylcholine has been outstanding depolarizing muscle relaxant for endotracheal intubation. It has some demerits as fasciculations, rise in serum potassium and CPK levels, increase in intraocular pressure, postoperative muscle pain, myoglobin in urine, etc. Also it is contraindicated in conditions as anticipated difficult intubation, liver disease, kidney disease, pregnancy, etc. Many studies have been conducted to minimize these side effects related to use of Succinylcholine, such as addition of pretreatment with non-depolarizing muscle relaxant (Abraham V et al 2008). ${ }^{1}$

In the present study, there was no variation in age distribution in three groups. There were no patients with extremes of age as like Hegarthy et al (1956). ${ }^{2}$ and Sharma et al (1971). ${ }^{3}$

In the present study, there was no significant difference as far as weight was concerned and it was in accordance with Puhringer FK et al (1995). ${ }^{4}$ and Weinstein JA et al (1988). ${ }^{5}$

\section{Fasciculations}

In the present study, the incidence of fasciculations was almost $100 \%$ in Group NS as compared to 48\% in Group V and 24\% in Group R. The severity of fasciculations was less in Group R as compared to Group V and Group NS. It is quoted that nondepolarizing muscle relaxants modify post Succinylcholine induced fasciculations by preventing pre-junctional depolarization and local axon reflexes, decreasing rate of motor unit firing. With this explanation, many authors have tried non-depolarizing muscle relaxants for this purpose Churchill Davidson et al (1954).6, DS Charak (1981). ${ }^{7}$ Mitchell Sosis et al (1984). ${ }^{8}$, PO Sullivan (1981). ${ }^{9}$, Ban Tsui (1988). ${ }^{10}$ True and Carter (2003). ${ }^{11}$ and Erkola 0 (1997). ${ }^{12}$ reported reduction in fasciculations after pretreatment with Vecuronium in their studies.

Findlay GP (1996). ${ }^{13}$, Rene Martin $(1981,1998) .{ }^{14}$ and V Abraham (2008). ${ }^{1}$ compared Vecuronium and Rocuronium for pretreatment before administration of Succinylcholine to see their effects. They observed that there is decrease in incidence and severity of fasciculations more with Rocuronium followed by Vecuronium. Our observations correlate with these authors.

\section{Intubating Conditions}

PO Sullivan (1988). ${ }^{9}$, GP Findlay et al (1996). ${ }^{13}$, Ban Tsui et al (1998). ${ }^{10}$ and Rene Martin et al (1998). ${ }^{14}$ have used Rocuronium and Vecuronium pretreatment before administration of Succinylcholine for endotracheal intubation. They observed no difference in intubating conditions in their patients with or without pretreatment of non-depolarizing muscle relaxants. In the present study also, there was no significant difference in Groups NS, V and R as far as intubating conditions were concerned. Pretreatment with Rocuronium offered better conditions than Vecuronium. There was no significant difference in intubation score in three groups.

In the present study, pretreatment with Rocuronium and Vecuronium significantly reduced the incidence and severity of Succinylcholine Myalgia on day 1 and day 3. Our observations coincide with that of $O$ Sulliven et al (1988). ${ }^{9}$ and Erkola et al (1990). ${ }^{12}$ In this regard, Rocuronium was found to be better than Vecuronium. Waters' and Mappalson postulated that Myalgia is secondary to damage produced in muscles by unsynchronized contraction of adjacent muscle fibers just before onset of paralysis, but many authors found no correlation between fasciculations and myalgia. Thus pretreatment with non-depolarizing agents suppresses the untoward action of Succinylcholine at neuromuscular junction.

The sustained depolarization of acetylcholine receptor by Succinylcholine leads to hyperkalaemia in normal individuals. This response is well tolerated, but clinically significant hyperkalaemia may occur in patients with metabolic acidosis, hypovolemia, severe trauma, uraemia, severe abdominal infection and muscle dystrophies. Birch et al (1969). ${ }^{15}$, AS Laurance (1985). ${ }^{16}$, RPF Scott et al (1998). ${ }^{17}$ observed that pretreatment with non-depolarizing muscle relaxant before administration of Succinylcholine significantly reduced the incidence and severity of hyperkalaemia in their patients. JH Kim et al (1999). ${ }^{18}$, V Abraham (2008). ${ }^{1}$ noted that pretreatment with Vecuronium and Rocuronium inhibits increase in serum potassium after Succinylcholine. Our observations coincide with above authors.

Tammisto and Airakesen (1966). ${ }^{19}$ observed that post Succinylcholine fasciculations cause straining of skeletal muscle fibers, which leads to efflux of muscle enzyme 
creatinine phosphokinase. Anoxia, hypoglycaemia, cooling, glucose tolerance, hyperkalaemia, thyroid dysfunction may cause release of CPK from muscle cell induced by Succinylcholine. DS Charak et al (1981). ${ }^{8}$ observed that pretreatment with non-depolarizing muscle relaxant or selftaming attenuates increase in CPK induced by Succinylcholine. Kim JH et al (1999). ${ }^{18}$ and V Abraham et al (2008). ${ }^{1}$ did not observe any significant increase in serum CPK after Succinylcholine within 24 hours pretreated with Vecuronium and Rocuronium. Our observations correlate with above authors and can be explained on same grounds.

Tammisto and Airksinen (1996). ${ }^{19}$ reported that presence of myoglobinaemia after intermittent doses of Succinylcholine and halothane anaesthesia. Fasciculations after administration of Succinylcholine leads to increase in serum CPK levels and secondary to damage of muscle cells, which leads to release of myoglobin in urine. AS Laurance et al (1988). ${ }^{16}$ showed that pretreatment with non-depolarizing muscle relaxants attenuate Succinylcholine induced increase in serum myoglobin. According to V Abraham et al (2008). ${ }^{1}$ pretreatment with Vecuronium or Rocuronium reduces increase in urine myoglobin after Succinylcholine in their patients. Our observations coincide with above author results. Hence, Rocuronium was found to be better than Vecuronium.

There were no dreadful intraoperative and postoperative complications in the present study.

\section{CONCLUSIONS}

Pretreatment with non-depolarizing muscle relaxant like Vecuronium or Rocuronium prior to administration of Succinylcholine significantly reduced the side effects of Succinylcholine like fasciculations, which in turn are responsible for postoperative Myalgia, hyperkalaemia, increase in serum CPK levels and myoglobinuria. In respect to efficacy of pretreatment, Rocuronium was better than Vecuronium. So it is advised to try Rocuronium or Vecuronium as pretreatment before Succinylcholine to avoid undesirable side effects related to Succinylcholine alone.

\section{REFERENCES}

1. Abraham V, Arti Raj Kumar, Afzal L. Evaluation of post succinylcholine myalgia and intubation condition with rocuronium pretreatment. a comparison with vecuronium. Indian Jr of Anaesth 2008;52(5):551-5.

2. Hegarthy P. Postoperative muscle pains. British Jr of Anaesth 1956;28:209-12.

3. Sharma M. Post Suxamethonium muscle pain. Indian Jr of Anaesth 1971;19:303.

4. Puhringer FK. Evaluation of endotracheal intubating condition of rocuronium and succinylcholine in outpatient surgery. Anaesth Analg 1995;75:37-40.
5. Weinstein JA, Matteo RS, Ornstein E, et al. Pharmacodynamic of vecuronium and atracuronium in obese surgical patients. Anaesth Analg 1988;67(12):114953.

6. Churchill Davidson. Succinylcholine and muscle pain. British Medical Jr 1954;1:74.

7. Charak DS, Dhar CL. Suxamethonium induced changes in serum creatinine phosphokinase. British Jr of Anaesthesia 1981;53:955-57.

8. Mitchel Sosis, Broad T, Larijani GE, et al. Comparison of atracuronium and d-tubocurarine for prevention of succinylcholine myalgia. Anasth Analg 1987;66(7):657-59.

9. O'Sullivan EP, Williams NE, Calvey TN. Differential effects of neuromuscular blocking agents on suxamethonium induced fasciculations and myalgia. British Jr of Anaesth 1988;60(4):367-71.

10. True CA, Carter PJ. A comparison of tubocurarine, Rocuronium and cisatracuronium in the prevention and reduction of succinylcholine induced muscle fasciculations. AANA J 2003;71(1):23-8.

11. Ban CH Tsui, Susan Reid, Sunil Gupta, et al. A rapid precurarization technique using rocuronium. Canadian Jr of Anaesthesia 1998;45:397-401.

12. Erkola 0. Effects of precurarization on suxamethonium induced postoperative myalgia during first trimester of pregnancy. Acta Anaesthesiologica Scand 1990;34(1):637.

13. Findlay GP, Spittal MJ. Rocuronium pretreatment reduces suxamethonium induced myalgia: comparison with vecuronium. British Jr of Anaesth 1996;76:526-29.

14. Rene Martin, Carrier J, Pirlet M, et al. Rocuronium is the best non-depolarizing relaxant to prevent succinyl choline fasciculations and myalgia. Canadian Jr anaesth 1998;46(6):521-5.

15. Birch AA Jr, George D Mitchell, George A Playford, et al. Changes in serum potassium response to succinylcholine following trauma. JAMA 1969;210(3):490-93.

16. Laurance AS. Biochemical changes following Suxamethonium Serum myoglobin, potassium and creatinine kinase changes before commencement of surgery. Anaesthesia 1985;40(9):854-9.

17. Scott RPF. Onset times and intubating conditions. British Jr of Anaesth 1998;80:417-19.

18. Kim JH, Cho H, Lee HW, et al. Comparison of rocuronium and vecuronium pretreatment of fasciculations myalgia and biochemical changes following succinylcholine administration. Acta anaesthesiologica scand 1999;37(4):173-8.

19. Tammisto, Airakesen. Suxamethonium induced myoglobinuria. British Jr of Anaesth 1996;37(6):464. 